\title{
Ambiguidades e contradições no discurso de naturofilia e nas práticas turísticas
}

\section{Ambiguities and contradictions in the love-of-nature idea and in touristic activities}

\author{
Maria Geralda ALMEIDA*
}

\begin{abstract}
RESUMO
O enfoque é para as concepções sobre a natureza, o ambiente e o turismo, procurando, sobretudo, considerar o sentido que a sociedade dá à sua relação com o espaço e com a natureza. A concepção de naturofilia configura-se como contraditória, pois estimula o turismo consumidor da natureza. As políticas destinadas ao turismo requerem mais cautelas e a autora aponta a responsabilidade compartilhada como uma alternativa na qual os diversos sujeitos assumem a gestão ambiental. Permeando essas questões, contribui-se para reflexões teórico-metodológicas sobre o ambiente, a natureza e o turismo.
\end{abstract}

Palavras-chave: natureza; ambiente; turismo; naturofilia.

\begin{abstract}
The focus of this study is on the concepts of nature, environment and tourism. It especially seeks to take into account the meanings that our society assigns to its relationship with space and nature. The loveof-nature concept figures as a contradictory term since it stimulates a consumerist tourism of nature. The policies directed to tourism require more caution, and the author stresses the idea of shared responsibility as an alternative that makes the different actors embrace environmental management. Through the discussion of these questions, we can contribute to the theoretical and methodological debate on environment, nature, and tourism.
\end{abstract}

Key-words: nature; environment; tourism; love-of-nature.

\section{Introdução}

A atividade turística, com raras exceções, quando praticada na natureza, tem se revelado como uma apropriação, uma modificação dos ecossistemas naturais. A existência dessa atividade está relacionada com a paisagem, para a implementação de infra-estruturas, de megaprojetos, nos quais a natureza tornou-se a mercadoria. Mesmo o ecoturismo, entendido como patrimônio natural e motivado pela reinvenção da natureza transformada em recurso turístico, representa, também, uma forma de

\footnotetext{
" Geógrafa, com mestrado e doutorado em Geografia pela Université de Bordeaux III. Atualmente é professora colaboradora da Universidade Federal de Sergipe e professora titular da Universidade Federal de Goiás, onde coordena o Núcleo de Estudos e Pesquisas em Cultura e Turismo do IESA/UFG. Contato: mgdealmeida@gmail.com.
} 
consumo da natureza. Isso leva a supor que turismo e ecologia são antagônicos.

Se atualmente cresce o interesse pela ecologia, isso se deve, também, à acelerada destruição do ambiente, o que compromete a reprodução da vida e do capital. Os princípios ecológicos comprometem-se, portanto, com a conservação do ambiente, isto é, das condições que asseguram a manutenção dos processos de acumulação.

Este artigo enfoca as relações entre a natureza, o ambiente e o turismo. Aqui, retraçarei, brevemente, a evolução do entendimento de natureza e de ambiente. Tentarei, adotando o que foi proposto por Augustin Berque (1986), considerar o sentido que a sociedade dá à sua relação com o espaço e com a natureza. E, nas modalidades das relações sociais, discutirei naturofilia como uma disposição afetiva, contemporânea, em relação à natureza, sobretudo instigada pelas práticas do turismo que, paradoxalmente, é produtor e consumidor do ambiente. Permeando essas questões, há uma outra intenção: contribuir para com reflexões teórico-metodológicas sobre o ambiente, a natureza e o turismo.

\section{As representações contemporâneas da natureza}

A emergência de uma preocupação nova, no que diz respeito à natureza, no último quarto do século XX, foi, em parte, resultante de releituras das concepções que, até então, definiram as relações sociedade-natureza, assim como, no entender de Eder apud Rudolf (1998), da maneira pela qual as sociedades representam e constroem aquela e, conseqüentemente, a sua natureza.

Quando presentemente a sociedade se interroga sobre suas relações com o meio natural, está, também, debatendo sobre a instrumentalização da natureza e uma construção simbólica dela. Nessa perspectiva, a crise ambiental teria o sentido de "violência" e aparece como um momento importante da nossa história, uma vez que ela cria uma ocasião ímpar de efetuar um retorno à socialização da natureza e apreender as dissonâncias entre a legitimação e a produção de ordem social existentes na modernidade. Isso estimula a vertente comunicacional da modernidade e age indiretamente sobre a práxis social.

Entretanto, a despeito dessa corrente questionadora de uma "crise ambiental", delineia-se uma vigorosa contracorrente impulsionada pela "descoberta" valorativa do natural que, pelas características históricas, configurase como uma reinvenção. Essa reinvenção se dá pela ressignificação e reafirmação das coisas naturais como partes e produtos da sociedade.

Foi com base na noção ocidental de natureza que se estruturou o imaginário que dá sentido ao mundo moderno e à sua cosmologia que possui uma concepção "naturalista" da realidade. De acordo com essa concepção, o meio natural é um âmbito material e objetivo que existe em si, de maneira exterior ao humano e independente de todo conhecimento. A separação entre o "humano" e "não-humano" tornou-se "natural", ainda mais que a fronteira divisória entre eles foi traçada pela sociedade dos humanos.

A oposição fundadora entre o natural e a sociedade não somente tem profundas implicações para a epistemologia da ciência como, também, constitui a base de nossa economia e da economia política. A civilização ocidental privilegiou a eficiência econômica em função da qual desenvolveu seu sistema de conhecimento. E nós, ao projetarmos nossa visão dicotômica da natureza como uma realidade ontológica, inviabilizamos os pressupostos e os contextos históricos nos quais ela surge, descartamos outras formas de conceber o natural e impedimos que a cosmologia ocidental moderna seja reconhecida como um discurso cultural particular. Como bem destaca Serje (1999, p. 11), o nosso olhar obtuso não alcança que "[...] não existe Natureza no singular. As naturezas são tantas quanto os grupos sociais”.

Várias foram as atitudes dos homens face à natureza, resultantes de diversas concepções que deram a ela: selvagem, sublime, pura, divina, objeto de conhecimento, útil, recurso. Tais concepções ainda se manifestam, com variações, nas relações "sociedade-coisa" naturais. Embora o entendimento sobre o natural tenha se ampliado, permanece em comum, nessas visões, a concepção de que ele é realidade alheia à intervenção social, um produto único e exclusivo das leis da seleção natural e a exclusão de sua dimensão histórica. Visualiza-se a natureza, então, como negação da vida urbana, da cultura e das práticas sociais. Esquece-se até que regiões florestais, montanhas íngremes, tidas como arquétipos do mais natural da natureza, se existem como tal, são lugares, produtos de relações e significações sociais, das práticas, dos medos e das preferências das sociedades que ali moram e/ou as definiram nesta função. O habitat e a paisagem de cada sociedade não são, portanto, unicamente conseqüência da "oferta natural" de solo, clima, vegetação, altitude, mas, 
sim, "o produto de um conjunto de dispositivos sociais, através dos quais algumas espécies se valorizam e se reproduzem, se selecionam e se preservam, e outras restam desfavorecidas" (SERJE, 1999, p. 39).

A natureza se reinventa contemporaneamente pelo seu valor de recurso, principalmente econômico, espetáculo e/ ou exibição, ilustrado aqui pelo ecoturismo, no segmento de contacto com a natureza. O ecoturismo visa o consumo das coisas naturais, que, depois de dessacralizadas, objetivadas e manipuladas pela sociedade capitalista, reencantam-se com valores antológicos. Assim, o discurso da conservação das espécies e dos atrativos turísticos naturais faz emergir outras leituras sobre a natureza, outros interesses e novos olhares valorativos. A naturofilia, expressão de Béteille (2000), alimenta tanto os mitos dos ecoturistas, as preocupações dos ecologistas e dos ambientalistas, quanto as fantasias daqueles que idealizam a natureza como sagrada e, paradoxalmente, os interesses financeiros daqueles que transformam a natureza em um produto vendável.

\section{Do entendimento de ambiente}

É vertiginosa a ascensão do conceito de ambiente. Ele aparece, no século XX, como uma grande revolução na forma de pensar o mundo e, mais particularmente, as relações do homem com a natureza.

Todavia, tanto o termo como o seu uso são fontes abundantes de confusões e digressões. Seus diversos sentidos permitem que todos falem sobre o ambiente e compreendam-no, entretanto, cada um à sua maneira.

O estudo da evolução semântica da referida palavra mostra que, inicialmente, ela foi entendida como uma referência ao não-vivo (clima, rocha, água); em seguida, ela ampliou-se para incluir as formações vegetais, depois as biocenoses, adotando uma concepção mais naturalista, de forte conotação biológica; o "ambiente natural". Só mais recentemente o termo "ambiente" infiltra-se nos domínios social, econômico e cultural - primeiramente, com implicações biológicas e, posteriormente, com referência à noosfera, a qual, segundo Theilhard de Chardin, está relacionada com a idéia de que a Terra, no seu infinito poder criativo, concebeu o ser humano a quem entregou a responsabilidade de gestar o futuro da vida no planeta. A noosfera está, pois, constituída pelo manto de idéias que cobre a Terra (apud NEGRET, 1994).
Conforme já foi discutido anteriormente, em artigo de Almeida (2000), cabe lembrar que o conceito básico de ambiente foi originalmente elaborado pela ecologia vegetal, no final do século XIX, que definiu o meio (natural) como o conjunto de condições externas e outras influências que afetam o crescimento e o ciclo de vida dos organismos vivos. Com a introdução do conceito de ecossistema, nos fins dos anos 1930, o meio natural é, cada vez mais, apreendido e concebido como o ambiente das sociedades pouco transformado ou não intensamente utilizado $\mathrm{e}$ degradado. Pouco-a-pouco, o ambiente ganha um corpo teórico transdisciplinar, talvez mais naturalista do que social. Porém, por parte de algumas correntes, e isso mais recentemente, o ambiente é interpretado com uma visão mais holística das relações natureza/sociedade.

No caso da Europa, no início dos anos setenta, no século XX, uma assimilação entre ambiente e meio geográfico confere tanto a um como a outro uma conotação naturalista. Na França, por exemplo, a partir de 1975, uma releitura é feita pelos geógrafos, que procuram situar o ambiente no contexto social; nos anos seguintes, diante do caráter global das relações natureza-sociedade, a abordagem geográfica evolui-se para a análise sistêmica. Já na década atual, novos temas surgem no seio das preocupações ambientais como poluição, catástrofes e riscos, gestão de recursos naturais, recursos naturais, geografia política e sustentabilidade. O trato desses temas é acompanhado do enriquecimento das abordagens metodológicas e teóricas.

Alguns autores, como Bertrand (1972), falamnos de ambiente como um sistema no qual interagem, simultaneamente e num mesmo espaço ou não, três esferas de componentes naturais e sociais: "ambiente natural", no qual as estruturas abióticas e bióticas funcionariam independentes dos componentes sociais; o "ambiente construído", em que se verifica a situação contrária, e; um "ambiente social", que resulta da complexa rede de relações/valores não visíveis e indiretamente perceptíveis que se estabelecem, de um lado, entre ambiente natural e grupos sociais e, de outro, nos próprios grupos sociais. Os problemas sociais seriam, assim, uma perturbação decorrente da inter-relação das três esferas ambientais.

Permeando aquele ou este entendimento, as interpretações dadas ao ambiente reforçam os mesmos aspectos: uma interconexão entre o sistema humano com o sistema natural. Cito como exemplo aquela proposta por J.J. Melo e C. Pimenta, apud Delvy-Vareta (1995, p. 21), que 
o define como " $[. .$.$] conjunto de sistemas físicos, ecológicos,$ econômicos e sócio-culturais com efeito direto ou indireto sobre a qualidade de vida do homem".

A problemática do ambiente envolve todas as ciências, particularmente, as do campo social. Atualmente, tanto nos cenários global e local como nos cenários presentes e futuros, discursos associam o ambiente com o desenvolvimento. Há uma ênfase na idéia de que o "verdadeiro" desenvolvimento é aquele compatível com a qualidade ambiental e com uma utilização sustentada dos recursos. Esse entendimento de ambiente iniciou-se durante a Conferência das Nações Unidas sobre Ambiente e Desenvolvimento - CUNAMD, em 1972, em Estocolmo. Fortaleceu-se na Conferência Rio-92, quando o ambiente e o desenvolvimento passaram a ser efetivamente considerados como dimensões norteadoras do progresso econômico e social. Essa discussão será posteriormente retomada nesse artigo. Merece agora uma reflexão sobre as imbricações entre o turismo e o ambiente.

\section{A invenção da atração turística e "naturofilia"}

Para o turismo, o ambiente resultaria de uma combinação entre o natural e o cultural. É a cultura que atribui significado subjetivo ao turismo. Soma-se a isso a dimensão econômica que ressignifica os aspectos cultural e natural para o turismo. O ambiente é, pois, "um território, isto é, uma mescla de natural e de artificial, uma humanização da natureza e uma naturalização do homem", no entender de Besse (1992, p.18), e o seu horizonte só tem sentido no contexto das representações humanas. Pode-se, portanto, referir-se a um ambiente turístico.

A cultura contém, desse modo, a compreensão e a leitura da natureza. Desta maneira, ela é entendida como o que tem sentido e dá sentido ao mundo, nas palavras de Berque (1986), e ela, também, qualifica o objeto turístico. Ela participa de sua invenção. O objeto turístico, assim como o valor cultural, não é imanente, não surge a partir desses mesmos objetos, práticas e idéias. Aquilo que chamamos de bens culturais não têm em si sua própria identidade, mas a identidade que os grupos sociais lhe impõem. O objeto turístico, portanto, em si, não existe. É uma invenção para e pelo turismo, conforme já o disse em artigos anteriores (ALMEIDA, 1998, 2006).
Os espaços, os lugares e os territórios turísticos também são invenções. Se quisermos discutir sua rápida expansão pelo espaço brasileiro, deverá ser à luz de que,

planejados, construídos pelos empreendimentos turísticos, ou mesmo decretados, institucionalizados, eles consistem, pois, no estabelecimento de nova estrutura socioespacial, cujo eixo de compreensão terá de emergir não da leitura do turismo, mas das relações da sociedade com o lugar e, mais ainda, dos homens entre si e na sociedade (ALMEIDA, 1998, p. 19).

Porém, conforme Dewailly e Flament (1993), o lugar só adquire valor turístico quando responde a uma demanda existente ou latente, quando se confunde com as aspirações, os gostos e mitos de uma época. Enfim, o desejo de experienciar, de sentir e conhecer, suscitado pela imagem que o turismo cria e pela propaganda que the dá corpo, faz com que o homem procure cada vez mais a fantasia, o simulacro, o exotismo, a nostalgia, o novo, o diferente. A natureza é a que mais se presta a atender os apelos do imaginário do homem citadino, por excelência, ele, o turista.

Vários são os estímulos: os recursos naturais como vegetação fora do comum, vida selvagem para ser observada e fotografada, áreas marítimas de arrecifes para observações e para prática de mergulho, cavernas, montanhas, cachoeiras e cursos d'água para diversas práticas desportivas, além da contemplação. Enfim, há uma progressiva apropriação/ destruição dos ecossistemas naturais pelo uso turístico.

A natureza, ao mesmo tempo em que fascina por seus cenários exuberantes, é vista pelo turismo como uma mercadoria que tem valor de uso. O turismo classifica tal natureza, a aprecia pela sua identidade passível de ser marketing e a promove no mercado. As pessoas que habitam tais lugares não vêem, contudo, que seu espaço é um atrativo no mercado turístico.

As atrações naturais pelas paisagens e imagens, bem como as atrações derivadas de herança cultural, como locais arqueológicos, históricos e religiosos, edifícios com uma arquitetura particular, museus, etnias, estilo de vida, festivais culturais, artesanato tradicional e contemporâneo dão reputação ao lugar, influenciam o imaginário e determinam a escolha das destinações pelos turistas. As atrações naturais definem, ainda, a afeição e encantamento pelo percebido e experienciado. 
Um exemplo da descoberta e evolução da importância da natureza nas atividades turísticas e, concomitantemente, da obtenção de ganhos econômicos, é o caso da França, relatado por Bétaille (2000). Por muito tempo, o mundo rural francês foi carregado de valores negativos no plano lúdico, fechado em suas funções de produção agrícola. Não se concebia imaginá-lo como portador de potencialidades turísticas. Também as paisagens naturais eram consideradas como pouco atraentes, com visitas apenas por breves “curiosidades" ocasionais. Já no século XIX, ocorreu uma reviravolta nessa concepção devido à descoberta do campo pelos intelectuais franceses. Autores como Balzac e Victor Hugo publicaram livros literários sobre as paisagens e os valores rurais; pintores retratam uma França bucólica. Realçam, assim, um país que cai no gosto da sociedade burguesa, que assume a curiosidade para conhecer a campagne francesa. A despeito dessa França, cuja representação idílica prevalece no seio artístico, geógrafos como Elisé Reclus divulgam novos conhecimentos sobre a chamada France profonde e enfatizam que as contradições sociais existiam e aquele país retratado pelos artistas deveria ser conhecido também cientificamente. Pouco a pouco, constituem-se os primeiros fluxos de visitantes. Eles vão, sobretudo, para as regiões naturais do Maciço Central, lugares de antigas peregrinações, pequenas estações termais. Consolida-se o interesse por um turismo de passagem e redescoberta da "terra natal". Na década de 1960-1970, passou-se de uma concepção de temporada espontânea ou esporádica no campo para uma valorização do mito neo-ruralista e para uma crescente valorização das chamadas vacances vertes. Esse movimento propunha romper com o "bronzeamento idiota" dos freqüentadores de praias e, simultaneamente, estimular o uso de lugares acolhedores em residências familiares, pequenos albergues surgidos com a iniciativa local e uma maior integração com uma natureza desconhecida. Os franceses, sensíveis a essa campanha, em grande parte aderem à naturofilia, principalmente respaldados na corrente ecológica e/ou na crença do turismo sustentável.

Essa crença generalizou-se. A sociedade contemporânea, com o turismo, re-valoriza uma natureza que já foi dessacralizada, objetivada e manipulada exaustivamente. Segundo Serrano (1997), na atualidade, é com base na representação da natureza como paisagem e como cenário para as ações humanas que se institui o consumo pelo turismo, o qual tem sua característica de consumo visual reforçada pela produção concreta de seus lugares turísticos, isto é, o ambiente construído, ou território, bem como pela representação da natureza como cenário, conforme já foi dito. Numa época em que as mudanças para uma economia do consumo e do lazer se fortalecem, o turismo ecológico, o turismo verde (ou ecoturismo, ou turismo natural) tornam-se os segmentos mais promissores de uma das atividades mais dinâmicas da economia mundial, graças a uma intensa vaga de naturofilia, isto é, ao desejo e sentimento de amor e aproximação da natureza por parte dos citadinos.

\section{Ecoturismo, suas contradições e as ambigüidades do desenvolvimento turístico sustentável}

Entre as atividades turísticas, o ecoturismo é o segmento que apresenta maiores taxas de crescimento. É o mais estimulado para as regiões ricas em ambientes naturais e, paradoxalmente, pobres em economia. É o caso do Brasil.

Segundo a Embratur, o ecoturismo é "um segmento da atividade turística que utiliza de forma sustentável o patrimônio natural e cultural, incentiva sua conservação e busca a formação de uma consciência ambientalista pela interpretação do ambiente, promovendo o bem-estar das populações" (BRASIL, 1994, p. 19).

Convém esmiuçar um pouco essa definição para entendermos tal modalidade de turismo. Em um primeiro momento, é evidente que o ecoturismo está formulado na vertente do uso e, simultaneamente, comercialização da natureza ao mencionar a intenção de promover o bemestar das populações. Ele está, também, em sintonia com o discurso do desenvolvimento sustentável. Por sua vez, este tem uma concepção embasada na compatibilização entre crescimento econômico e preservação ambiental; também enfatiza a necessidade de garantir o patrimônio ecológico para gerações presentes e futuras. Ora, considerando o elitismo que permeia o ecoturismo, é questionável quais as populações que teriam assegurado o uso do patrimônio ecológico de imediato e futuramente.

De acordo com Beker (apud DAVIDOVICH, 1993, p. 83), a proposta de desenvolvimento sustentável objetiva uma regulamentação globalizada do desenvolvimento, definindo papéis e diretrizes específicas para países periféricos. As conotações políticas e estratégicas dessa tese são numerosas. 
Significa maior controle do crescimento econômico de países economicamente dependentes. O desenvolvimento sustentável seria, portanto, um "instrumento político de regulação do uso do território". Ele revela-se, também, contraditório: ao mesmo tempo em que acena para o crescimento econômico desses países, propõe sua subordinação à primazia da conservação do meio ambiente. Esse paradoxo tem sua razão por se respaldar na defesa de um liberalismo total da economia.

Para diversos autores, críticos da economia liberal, o desenvolvimento sustentável representaria uma estratégia para a consolidação de uma composição política que envolve hegemonia universal e soberanias limitadas. Assim, apesar da aparente neutralidade e da tentativa de apontar sua preocupação com a educação e conservação ambiental, esse estilo de desenvolvimento não consegue ocultar completamente o sentido de mercantilização da natureza, típico da atividade turística. E mais: o recurso à sustentabilidade possibilita que o turismo, como uma prática econômica, apresente-se como tendo um fim em si mesmo: exploração "não destrutiva da natureza" para gerar recursos para "conservar a natureza" / "atrativos conservados" / "proteger a natureza", conforme Silva (1997, p.146). De acordo com esse autor, tal circularidade impede questionamentos que pudessem reverter o sentido histórico dessa e das outras práticas econômicas da sociedade.

É inegável o interesse e o crescimento da demanda por atividades ecoturísticas. Todavia, aproveitando-se deste rótulo, observa-se uma vulgarização do termo aplicado para vender pacotes de passeios, excursões ou visitas para qualquer ambiente natural. Ecoturismo tornou-se equivocadamente sinônimo de natureza, afirma Boo (1992). De fato, a forte percepção mundial acerca da necessidade urgente de proteção e recuperação dos recursos naturais, originária, principalmente, da disseminação dos movimentos conservacionistas empreendidos por grupos ambientalistas, forças políticas e marketing, acaba por influenciar nos roteiros e destinos dos ditos "ecoturistas". Nega, entretanto, uma outra vertente do ecoturismo, ou seja, a valorização do patrimônio cultural e das sociedades tradicionais portadoras de conhecimentos sobre os ambientes considerados naturais. Na maioria das vezes, elas são até excluídas dos roteiros e programas oficiais que são vendidos na mídia.

Em discussões anteriores (ALMEIDA, 1998, 2003), afirmo que o turismo tem o olhar ambíguo. O olhar extasiado confunde-se com o olhar valorativo. Assim, é com base na representação da natureza, como paisagem, e da apropriação dela pelos interesses capitalistas que se institui seu consumo pelo turismo. Numa época em que a "religião" das coisas naturais está em quase todas novas espiritualidades, o turismo ecológico, ecoturismo, turismo natural ou turismo em meio rural, não importa qual denominação, fortalece-se como um dos segmentos mais promissores da reinvenção da natureza.

Considerando que a natureza foi idealizada como realidade oposta à cidade e à vida citadina, o desejo de usufruir da natureza surge como justificativa para alguns, guiados pela necessidade de sentirem-se de acordo e em harmonia com o cosmos, com o universo, com o ambiente e, sobretudo, com a consciência de "estar aqui" (SERJE, 1999). É a naturofilia, já dissemos, a motivadora desse desejo e necessidade. Entretanto, alguns autores alertam que a união com o natural é um pretexto e não um objetivo. A suposta magia da comunhão com a natureza realiza uma série de operações simbólicas que nunca perde de vista a identidade social de qualquer um de seus participantes. De fato, no caso do Brasil, no Cerrado do Planalto Central, entorno do Parque Nacional da Chapada dos Veadeiros$\mathrm{GO}$, toda uma hierarquia social é ratificada por trás do eufemismo "imagem idílica de Alto Paraíso"-GO: os "nativos" participam como guias, informantes, como subalternos dos proprietários das pousadas ou como proprietários de restaurantes e pousadas de categorias inferiores nas comunidades alternativas. A comunicação com a população tradicional restabelece-se através da lógica da dádiva, do material e a do reconhecimento, em troca de informações sem as quais a dita comunhão com a natureza seria impossível. A magia do ecoturismo logra, de fato, ocultar a violência simbólica que se encontra inscrita na relação assimétrica dos interlocutores sociais.

Entretanto, o ecoturismo inclui-se no paradigma do desenvolvimento sustentável, visto como uma prática que a priori visaria o bem-estar da população envolvida. Esse aspecto já foi mencionado e, também, cito Silva (1997), que alerta sobre esse paradoxo. Tal autor acrescenta outros elementos representativos da inscrição do ecoturismo na sociedade moderna: na contradição do exercício de práticas econômicas dentro de uma determinada legalidade ambiental; na contradição entre a concepção naturalista e a concepção socioambiental da natureza e na contradição entre o discurso da preservação do natural e a intensificação de práticas econômicas de exploração das coisas naturais. 
Natureza e turismo realizam uma aliança notável para promover o chamado turismo ecológico, turismo verde, turismo em meio rural ou ecoturismo. A naturofilia, de fato, obscurece como a natureza torna-se mais um recurso, entre tantos outros que os biomas encerram.

Um outro aspecto importante a ser abordado é a propagada contribuição do ecoturismo na "formação de uma consciência ambientalista pela interpretação do ambiente", segundo a própria definição da Embratur, já apresentada nesse texto. Dito de outra maneira, é considerar o ecoturismo, por excelência, uma forma de se educar sobre o ambiente e de se interessar, e muito, pela biodiversidade.

Depois de séculos de destruição sistemática da vida e da natureza, vista como um mundo exterior de matériasprimas, assiste-se a um crescente interesse por parte do capital e da ciência na manutenção da diversidade biológica. A "erupção do biológico", como um fato social central das políticas globais do final do século XX e início do atual, coloca as áreas tropicais, ou seja, no caso, o Cerrado, em uma posição biopolítica global fundamental. Vivemos um momento de ressignificação das áreas tropicais, como valiosa reserva genética, e de suas populações tradicionais como portadoras de conhecimentos de conservação da natureza.

No caso do Brasil, fala-se muito sobre a Amazônia e se esquece do Cerrado. Há uma exuberância da biodiversidade do Cerrado. Os genes das espécies selváticas constituem-se uma valiosa biblioteca de informação genética, fonte de drogas e, talvez, reserva de abundância de medicamentos, cosméticos e alimentos que poderiam converter-se em produtos valorizados mediante a biotecnologia. As áreas de Cerrado constituem-se um espaço social onde se observa a reinvenção da natureza, a busca de sistemas econômicos alternativos e a persistência de modos de vida tradicionais, a despeito de uma recente hibridação cultural que ocorre, conforme Canclini (1989), entre formas modernas e nãomodernas motivadas pelas ações de desenvolvimento com o biocombustível e o agronegócio.

$\mathrm{O}$ discurso da biodiversidade promete salvar a natureza das práticas destruidoras e em seu lugar instituir uma cultura da conservação. É uma nova maneira de falar sobre a natureza dentro de uma profunda mediação técnicocientífica e é, também, uma nova interface entre a natureza, o capital e a ciência.
De acordo com as instituições dominantes, sobretudo de acordo com os interesses da indústria químicofarmacêutica, a chave para a conservação da biodiversidade está na utilização dos recursos de modo a garantir sua conservação a longo prazo. Os padrões de significadouso dos recursos naturais são de grande importância na teorização e quantificação da biodiversidade. $\mathrm{O}$ dito uso, na opinião daquelas instituições, deve-se fundamentar no conhecimento científico da biodiversidade, em sistemas apropriados de administração e em mecanismos adequados que estabeleçam os direitos da propriedade intelectual e que protejam as descobertas passíveis de serem comercializadas. A Estratégia Global para a Biodiversidade, elaborada em 1991, apoiando-se na tríade conhecer-salvar-usar, tem promovido por diversos meios a caça aos genes, justificando-a como necessária para salvar a natureza e afirmando que a fonte dos benefícios e das ganâncias da conservação está nesses genes. O ecoturismo tem permanecido à margem dessas discussões e viabiliza somente uma prática empobrecedora, vulgarizada como atividade lúdica. Contudo, face ao interesse manifesto dos grandes grupos e instituições dominantes pela biodiversidade, ele poderia assumir a vertente da educação ambiental e bem-estar das populações envolvidas e ser um aliado das populações tradicionais para a manutenção e conservação de seus saberes sobre o Cerrado e sobre a biodiversidade local.

\section{A convivência com o ambiente "turistificado"}

O estresse dos tempos modernos e a efervescência da vida nas cidades favorecem a busca cada vez maior do contato com a natureza, sobretudo, em áreas minimamente alteradas, ou em áreas protegidas. Conforme já foi dito, cresce a naturofilia, pois, além da afeição, os visitantes da natureza têm a crença de que ela repõe as energias gastas e cria novo alento para enfrentar o ritmo urbano.

Baseando-se nessa crença, a prática turística é estimulada em unidades de conservação e várias vantagens são alegadas por seus defensores: a adesão de visitantes às tarefas de fiscalização; o aumento da oferta regional de espaços de lazer e recreação; a possibilidade de uma maior integração das áreas protegidas com comunidades locais e com a sociedade de maneira mais ampla; divulgação ambiental via programas educativos e da própria visitação; 
e o estabelecimento de "redes" de interessados em sua manutenção (Boo, 1992). No caso do Brasil, em 2004, o semi-árido nordestino possuía 22 Unidades de Conservação (UC's), sendo 6 delas parques nacionais, com destaque para o Parque Nacional Serra da Capivara-PI , um dos mais visitados. Na Mata Atlântica, o IBAMA delimitou 71 UC's, sendo que 19 são parques nacionais e 11 estão estruturados para ecoturismo, como o Parque Nacional da Tijuca, Serra dos Órgãos e Serra Itatiaia no Rio de Janeiro, sobretudo, para caminhadas e observação de fauna, da flora e do turismo de cavernas (www.brasiltur.com).

Seabra (2007) menciona alguns projetos turísticos existentes no interior do Nordeste que, em sua avaliação, se apresentam "com algum êxito", como Chapada Diamantina (BA), Caminho das Pedras e Serra do Catimbau (PE), Lajedo de Pai Mateus e o Vale dos Dinossauros (PB), Lajedo de Soledade (RN), Serra da Capivara e Sete Cidades (PI). Alguns deles estão implantados em unidades de conservação. Entretanto, numerosos são os estudos que apontam para os problemas decorrentes da "turistificação", isto é, o processo de implementação dessas atividades nos diversos ambientes. Ainda no mesmo artigo, Seabra (2007) destaca que, na maioria dos projetos implantados no interior nordestino, existe a ausência da inclusão social e de medidas destinadas à preservação ambiental e cultural. Os espaços naturais de "rara beleza cênica" transformam-se em territórios turísticos pela implantação de equipamentos turísticos; determinados espaços naturais deterioram-se ou reduzem-se. As paisagens banalizam-se e perdem o encanto e a possibilidade de evocarem a aventura e a fantasia. Além disso, as edificações podem levar a processos erosivos de difícil contenção, tornando a degradação do solo e sua exposição às intempéries cada vez maior.

$\mathrm{O}$ desejo de ter uma maior proximidade com a natureza contribui, também, para com o processo de especulação imobiliária que secundariza as características ambientais e leva à ocupação de dunas, manguezais, falésias e florestas e à privatização de praias ao longo do litoral brasileiro.

Há, também, um empobrecimento gradativo de valores da cidadania e do financeiro quando as atividades tradicionais de agricultura, pesca e extrativismo são substituídas por outras atreladas a um turismo sazonal. A desconsideração dos elementos culturais locais no desenvolvimento de atividades turísticas está relacionada, igualmente, à degradação ambiental.
No caso da instalação de equipamentos turísticos, a população local, muitas vezes, é desenraizada do seu local de moradia e de sua atividade de trabalho. A perda da terra e do trabalho desterritorializa tal população e fragiliza seus valores locais.

No que diz respeito ao turismo em áreas protegidas, autores apontam os seguintes impactos: necessidade de "sacrifício" de áreas para descanso e para aberturas de trilhas e acessos; construção de infra-estrutura na compactação, na erosão e na abertura de atalhos em trilhas; depredação da infra-estrutura, das rochas e das árvores por pichações ou na coleta de souvenirs; no distúrbio do ambiente sonoro, visual e olfativo da fauna, por barulho, excesso de cores e odores estranhos ao meio.

\section{Considerações finais}

Diante desse quadro contraditório de vantagens e desvantagens para a dinâmica ambiental, o turismo destacase, pois, como o produtor dos lugares turísticos relacionados com a natureza e a cultura - e emerge como aquele que cria, contraditoriamente, a sua própria destruição.

É possível "turistificar" sem destruir as especificidades ambientais consideradas como bens turísticos? Casos de ocorrência de uma valorização de maior participação por parte de comunidades e populações locais na definição do tipo de turismo e no planejamento do turismo desejável são registrados como experiências bem sucedidas. Também é lembrada a valorização dos procedimentos de parceria entre atores públicos, privados e associativos na busca de estratégias que conciliem conservação e turismo.

Um elemento fundamental de uma política de turismo e gestão ambiental eficaz e socialmente aceita é o conceito de responsabilidade compartilhada. Responsabilizarse compartilhadamente consiste em trocar uma visão de um trato das questões ambientais, em que, de um lado, existem os agentes infratores e do outro o Estado fiscalizador-punidor, por uma outra, na qual há uma responsabilização de todos os agentes sociais. Estes, governamentais e não-governamentais, desempenham as tarefas articuladas e complementares que permitem alcançar objetivos ambientais em torno dos quais são estabelecidos um consenso social, diálogo e senso comum. Além disso, a transparência da tomada de decisão é condição necessária para uma efetiva co-responsabilidade. 
Cabe aos formuladores de políticas ambientais, com o auxílio da sociedade civil, desembaraçar-se do conceito de "desenvolvimento sustentável"; conceito vago, ambíguo, de duvidosa operacionalidade prática e, sem dúvida, politicamente apelativo. Freqüentemente, o desenvolvimento sustentável é utilizado para justificar as mais variadas e contraditórias decisões diante dos problemas de desenvolvimento. Todavia, as conseqüências sobre a qualidade do ambiente e o equilíbrio do suporte ecológico ainda carecem de mais estudos e merecem restrições na sua aplicação.

Tornou-se claro, a partir dos fins da década de oitenta, do século XX, convém frisar, que não é possível equacionar as questões de ambiente descontextualizadas do aspecto econômico, e vice-versa.

O turismo é híbrido e, simultaneamente, um enorme potencial de desenvolvimento econômico, por um lado, e de degradação do ambiente, por outro. Híbrido, também, no sentido de ser o turismo um produtor e consumidor de ambiente. Entretanto, no contexto atual de valorização dos aspectos econômicos do turismo, os planejadores e empreendedores têm negligenciado os estudos e a

\section{Referências}

ALMEIDA, M.G. A produção do ser e do lugar turístico. In: SILVA, J.B.; LIMA, L.C.; ELIAS, D. (Orgs.). Panorama da Geografia brasileira 1. São Paulo: Annablume, 2006, p. 99122.

Lugares turísticos e a falácia do intercâmbio cultural. In: ALMEIDA, M.G. Paradigmas do turismo. Goiânia: Alternativa, 2003, p. 11-22.

Algumas inquietações sobre ambiente e turismo. In: MENEZES, A. V. C.; PINTO, J. E. S. (Orgs.). Geografia 2001. Aracaju: NPGEO, 2000, p. 51-64.

. Cultura - invenção e construção do objeto turístico. In: Espaço Aberto 3 - Turismo e formação profissional. Fortaleza: AGB/FUNCAP, 1998, p. 17-33.

BERQUE, A. Le sauvage et l'artifice: les Japonais devant la nature. Paris: Gallimard, 1986.

BERTRAND, G. Paisagem e Geografia Global: esboço metodológico. Trad. Olga Cruz. Caderno de Ciência da Terra. Sao Paulo: USP-IGEOG, n. 43, 1972. consideração dos aspectos relacionados com a natureza, a cultura e os aspectos psicossociais dos locais receptores. Um conflito de concepção manifesta-se, por exemplo, nas políticas setoriais: no caso do litoral, a política de turismo é eminentemente desenvolvimentista, enquanto que a política do Ministério do Meio Ambiente para essa região é nitidamente ambientalista. Ora, a ação do homem é rápida. Perturba o comportamento da natureza. As respostas dela, contudo, adaptando-se às novas situações criadas pelo comportamento humano, são lentas. O tempo tem um duplo referencial: um tempo curto para a ação humana e um tempo longo para o comportamento e reação da natureza. Em outras palavras, turismo e ecologia estão em descompasso temporal.

Deve-se considerar, também, que os planos e os projetos de regeneração de ambiente somente dão resultados após um longo lapso de tempo. Os mandatos dos políticos são bem mais curtos, e as prorrogações de prazos dos mandantes não representam nada, confrontadas ao tempo de ajuste e de regeneração da natureza face a uma agressão ou a uma prática destruidora.

BESSE, J-M. Le point de vue du philosophe. In: A.F.D.G. Spécial géoforum - Géographes Associés. GAN 10, Université de Bourgonge/CNRS, $1^{\text {er }}$ semestre de 1992, 1992.

BÉTEILLE, R. Le tourisme vert. (Collection Que sais-je?). Paris: PUF, 2000.

BOO, E. Ecoturismo: potencialidades e vias. Mimeo., 1992.

BRASIL. Diretrizes para uma política nacional de ecoturismo. Brasília: Embratur, 1994.

BRASILTUR. Disponível em: <http://www.brasiltur.com>. Acesso em: 12/04/2007.

CANCLINI, N. G. Culturas híbridas: estratégias para entrar y salir de la Modernidad. México: Grijalbo, 1989.

DAVIDOVICH, F. A propósito da Eco-Urb's 92: a temática urbana na questão ambiental. In: MESQUITA, O. O.; TIETZAMANN, T. S. (Coords.). Geografia e a questão ambiental. Rio de Janeiro: IBGE, Departamento de Geografia, 1993. 
DEWAILLY, Jean-Michel; FLAMENT, Emile. Géographie du tourisme et des loisirs. Paris: Sedes, 1993.

DELVY-VARETA, N. D. Geografia, vegetação e problemática ambiente. In: Forgeo. Ambiente e Território, v. 9 e 10. Lisboa: Associação Portuguesa de Geógrafos, 1995.

FARIA, D. S.; CARNEIRO, K. S. Sustentabilidade ecológica e turismo. Brasilia: Editora UnB, 2001.

MOLINA, S. Turismo e ecologia. Bauru, SP: EDUSC, 2001.

NEGRET, R. Na trilha do desenvolvimento sustentável: ecologia natureza sociedade. Alto Paraíso: ITDS, 1994.

RUDOLF, F. L'environnement, une construction sociale: pratique et discours sur l'environnement en Allemagne et en France. Strasbourg: Presses Universitaires de Strasbourg, 1998.
SEABRA, G. Turismo sertanejo. João Pessoa, PB: Editora Universitária/UFPB, 2007.

SEBRAE. Turismo ecológico. 4. ed. Porto Alegre: Ed. SEBRAE. Série Desenvolvendo o Turismo, v. 2. 2002.

SERJE, M. R. La concepción naturalista de la naturaleza: un desafio al ambientalismo. In: Revista de Antropologia y Arqueologia. Universidad de los Andes, v. 11, n. 1-2, p. 5-70, 1999.

SERRANO, C. M. A vida e os parques: proteção ambiental, turismo e conflitos de legitimidade em unidades de conservação. In: SERRANO, C. M.; BRUHNS, T. (Orgs.). Viagens à natureza: Turismo, cultura e ambiente. Campinas: Papirus. 1997.

SILVA, T. O. Ambiente e o turista: uma abordagem discursiva. In: SERRANO, M. C.; BRUNHS, H. T. (Orgs.). Viagens à natureza: turismo, cultura e ambiente. Campinas: Papirus, 1997. 